\title{
Preliminary estimates of French deepwater fishery discards in the Northeast Atlantic Ocean
}

\author{
V. Allain ${ }^{a, b_{*}}$, A. Biseau ${ }^{b}$ and B. Kergoat ${ }^{b}$

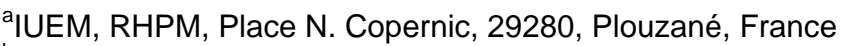 \\ ${ }^{\mathrm{b}}$ IFREMER, 8 rue F. Toullec, 56100, Lorient, France \\ *: Corresponding author : valeriea@spc.int
}

\begin{abstract}
French deepwater fish exploitation $(500 \mathrm{~m})$ began off the West coast of the British Isles in 1973. It further developed in the 1980s, and intensified in the 1990s. In 1997, the French fleet comprised 49 boats, and since 1995 has landed yearly about 19,500 t of deepwater fish species, of which, the grenadier Coryphaenoides rupestris (Macrouridae) has been the most abundant. Discard data were sampled on-board by observers on French high sea trawlers from 1995 to 1997. Eight species were identified as totally landed, 43 non-commercial species as totally discarded and only one, the grenadier, as both landed and discarded. The mean discarding rate by haul was $48.5 \%$ in weight, whereas the mean grenadier discarding rate was $21.2 \%$; these rates increased with depth. Discard species composition and discard quantities varied with depth, and depended on the specific composition of the fish communities, species abundance and their length-frequency distribution. The latter, established for grenadier and Alepocephalus bairdii (Alepocephalidae), assumes a bathymetric ontogenic migration. Annual discards of the fishery accounted for about 17,500 t in 1996 and 1997, but the results are quite uncertain.
\end{abstract}

Keywords: Alepocephalus bairdii; Coryphaenoides rupestris; Discarding rate; Discards; Lengthfrequency distribution 


\section{Introduction}

The exploitation of deepwater species by the French fleet began in 1973 when blue ling Molva dypterygia (Pennant, 1784) (Lotidae) were caught off the West coast of the British Isles in depths of $500-600 \mathrm{~m}$. This fishery developed throughout the 1980s and intensified throughout the 1990s with the landing of additional species taken in deeper water (down to $1400 \mathrm{~m}$ ) such as roundnose grenadier Coryphaenoides rupestris (Gunnerus, 1765) (Macrouridae), black scabbard fish Aphanopus carbo (Lowe, 1839) (Trichiuridae) and orange roughy Hoplostethus atlanticus (Collett, 1889) (Trachichthyidae) (Charuau et al., 1995). This fishery takes place in ICES Divisions V, VI and VII and is undertaken by high-seas trawlers (Lorance and Dupouy, 2001). In 1997, 49 boats participated in the fishery, of which 21 were specialised for it (i.e. they spent more than $50 \%$ of their annual fishing hours targeting deepwater fishes) (Allain, 1999a). In 1997, around $19000 \mathrm{t}$ of deepwater species were landed, including $7200 \mathrm{t}$ of $C$. rupestris.

Only a few species are targeted by the French fishery; the non-commercial species or small individuals are discarded. Because of physiological injuries, fish do not survive the rapid raising from several hundred meters depth, and are discarded dead or dying. Discards of commercial species contribute to fishing mortality and should be quantified for stock management purposes. Furthermore, discards represent an economic and ecological waste, and seeking solutions to alleviate the problem requires local studies to determine the scale and variability of discarding (Saila, 1983). Our study conducted from 1995 to 1997 on French high-seas trawlers, is complementary to two other studies on deepwater fishery discards conducted at the same time and in the same area by Connolly and Kelly (1996) and Blasdale and Newton (1998). Our aim was to identify the species discarded, to determine their discarding rate and to provide a preliminary estimate of the total quantities discarded by the French deepwater fleet.

\section{Material and methods}

The weights of landed and discarded fish were estimated by on-board observers for 55 trawl hauls made at depths between $800 \mathrm{~m}$ and $1400 \mathrm{~m}$, and sampled during eight two-week trips on two highseas trawlers (38 m long). These trips took place between December 1995 and September 1997 at the rate of one per quarter. The fishing area was off the West coast of the British Isles, between $47^{\circ} \mathrm{N}$ $7^{\circ} 30^{\prime} \mathrm{W}$ and $59^{\circ} \mathrm{N} 15^{\circ} 45^{\prime} \mathrm{W}$, and the fishing gear was a bottom trawl with a $100 \mathrm{~mm}$ (stretched mesh) codend.

The fish were sorted by species and identified from the check list given by Whitehead et al. (1984). Rays were grouped in the family Rajidae and some unidentified Dalatiidae were also recorded by their family name. The two sharks Centrophorus squamosus (Bonnaterre, 1788) (Centrophoridae) and Centrocymnus coelolepis (Bocage \& Capello, 1864) (Dalatiidae) were grouped under their commercial name, 'siki'.

On board, the fishermen estimated the number of $50-\mathrm{kg}$ boxes of each species retained for landing, while the scientific observers counted all the discarded fish. Because of the difficulties of weighing at sea, and because the length distributions of most species were very narrow, numbers of discarded fish and weights of landed fish were converted into approximate weights and numbers, respectively. The values in Table 1 were obtained from series of measurements carried out to establish, for a species, the number of individuals in a given weight. The weights of scarce or small species were not estimated.

Data were standardized to a four-hour haul, which is the typical duration of a commercial tow. The total- or by species-discarding rate is the discarded weight-to-caught weight ratio.

Two methods were considered for estimating the total weights of fish discarded by the fleet each year: one based on fishing effort, and the other based on the discarded-to-landed ratio. The effort method was tested by extrapolating the quantities of landed grenadier sampled on-board for the whole fleet. Differences between estimated and observed landings varied between $-67 \%$ and $+52 \%$ per quarter (Allain, 1999a). The effort method was not used for these preliminary results. Moreover, real effort is difficult to estimate because the proportions of time spent on deep-sea and continental shelf fishing grounds during the same trip are not known. The estimates of the total weights of fish discarded by the fleet each year were then based on the observed ratios of the weights of discards to the landed weights of roundnose grenadier, Coryphaenoides rupestris. C. rupestris was chosen as the reference species because it was the target species of the fishery, it was the only species both landed and 
discarded, and it was the most common species in the catches of deepwater commercial trawlers (Allain and Kergoat, 1997).

Table 1.

Relationship between the number of fish (No.) and weight (kg) of the most abundant discarded and landed species.

\begin{tabular}{lcclcc}
\hline Discards * & No. & $\mathrm{kg}$ & Landings ** & No. & $\mathrm{kg}$ \\
\hline Coryphaenoides rupestris & 100 & 40 & Coryphaenoides rupestris & 60 & 50 \\
Alepocephalus bairdii & 15 & 48 & Aphanopus carbo & 54 & 50 \\
Deania calcea & 12 & 39 & Siki & 9 & 50 \\
Lepidion eques & 100 & 37 & Hoplostethus atlanticus & 20 & 50 \\
Trachyrincus murrayi & 150 & 37 & Molva dypterygia & 11 & 50 \\
Hydrolagus mirabilis & 17 & 40 & Mora moro & 47 & 50 \\
Hydrolagus affinis & 30 & 13 & Lophius piscatorius & 10 & 50 \\
Caelorinchus labiatus & 150 & 37 & Trachyscorpia crist. echinata & 21 & 50 \\
Alepocephalus rostratus & 55 & 48 & & & \\
Rhinochimaera atlantica & 5 & 30 & & & \\
Halargyreus johnsonii & 150 & 32 & & & \\
Harriotta raleighana & 10 & 22 & & & \\
Sharks & 24 & 39 & &
\end{tabular}

* Five baskets were weighed per species, the inter-baskets differences were less than $3 \mathrm{~kg}$.

** Five 50 kg-boxes were counted per species, the inter-boxes differences were less than 5 individuals.

The mean and pooled ratios (Table 2) were applied to the total annual landings of $C$. rupestris to estimate the quantities rejected each year by the whole fleet. Annual landings of deepwater fish were extracted from French statistical data.

The length-frequency distributions of the two main discarded species were established. $A$. bairdii standard lengths were used to measure 31 randomly sampled sets of 10 to 200 individuals caught between 780 and $1300 \mathrm{~m}$ depth. Roundnose grenadier $C$. rupestris were measured from the tip of the nose to the first ray of the anal fin, i.e. the pre-anal length. Thirty-two sets of landed fish (1 to 2 baskets of 15-120 individuals per set), and discarded fish (0.5 to 1 basket of 15-100 individuals per set) were randomly sampled from the same hauls. All fish were caught between 860 and $1300 \mathrm{~m}$. Next, the total quantity of grenadiers landed and discarded during each haul was estimated and the landed weight to discarded weight ratios applied to the respective proportions of the landed and discarded sub-samples to establish the length-frequency distributions of the total catch.

Table 2.

Mean and pooled discarded species-to-landed grenadier weight ratios per year; mean over 28 hauls in 1996 and 19 hauls in 1997, confidence interval $(p=0.05)$ and percentage that confidence interval represents compared to mean, minimum and maximum values by haul and pooled annual ratio (sum of the discard weights from all sampled hauls of the year/ sum of the landing weights from all sampled hauls of the year).

\begin{tabular}{|c|c|c|c|c|c|c|c|c|}
\hline & \multicolumn{2}{|c|}{$\begin{array}{c}\text { Discarded grenadier- } \\
\text { to-landed grenadier } \\
\text { ratio }\end{array}$} & \multicolumn{2}{|c|}{$\begin{array}{l}\text { Discarded } A \text {. bairdii- } \\
\text { to-landed grenadier } \\
\text { ratio }\end{array}$} & \multicolumn{2}{|c|}{$\begin{array}{l}\text { Discarded other } \\
\text { species- } \\
\text { to-landed grenadier } \\
\text { ratio }\end{array}$} & \multicolumn{2}{|c|}{$\begin{array}{l}\text { Discarded all species- } \\
\text { to-landed grenadier } \\
\text { ratio }\end{array}$} \\
\hline & 1996 & 1997 & 1996 & 1997 & 1996 & 1997 & 1996 & 1997 \\
\hline Mean & 0.316 & 0.213 & 2.569 & 1.871 & 0.693 & 0.459 & 3.584 & 2.544 \\
\hline $\begin{array}{l}\text { Confidence } \\
\text { interval (\%) }\end{array}$ & $\begin{array}{c}0.075 \\
(21.87)\end{array}$ & $\begin{array}{c}0.074 \\
(33.33)\end{array}$ & $\begin{array}{c}1.637 \\
(63.81)\end{array}$ & $\begin{array}{c}0.698 \\
(37.43)\end{array}$ & $\begin{array}{c}0.173 \\
(24.64)\end{array}$ & $\begin{array}{c}0.157 \\
(34.78)\end{array}$ & $\begin{array}{c}1.718 \\
(48.04)\end{array}$ & $\begin{array}{c}0.775 \\
(30.31)\end{array}$ \\
\hline Minimum & 0.044 & 0.013 & 0 & 0 & 0.058 & 0.029 & 0.523 & 0.186 \\
\hline Maximum & 1.018 & 0.752 & 20.640 & 6.512 & 1.774 & 1.791 & 21.883 & 7.038 \\
\hline $\begin{array}{l}\text { Pooled } \\
\text { annual ratio }\end{array}$ & 0.311 & 0.213 & 1.533 & 1.749 & 0.551 & 0.410 & 2.395 & 2.369 \\
\hline
\end{tabular}


Table 3.

Mean quantity by weight (kg) and by number (No.) per four-hour haul of the landed (L) and discarded (D) species.

\begin{tabular}{|c|c|c|c|c|c|c|c|c|c|}
\hline & $\begin{array}{c}\mathrm{L} \\
(\mathrm{kg})\end{array}$ & $\begin{array}{c}\mathrm{L} \\
\text { (No.) }\end{array}$ & $\begin{array}{c}\text { D } \\
(\mathrm{kg})\end{array}$ & $\begin{array}{c}\text { D } \\
\text { (No.) }\end{array}$ & & $\begin{array}{c}\mathrm{L} \\
(\mathrm{kg})\end{array}$ & $\begin{array}{c}\mathrm{L} \\
\text { (No.) } \\
\end{array}$ & $\begin{array}{c}\mathrm{D} \\
(\mathrm{kg})\end{array}$ & $\begin{array}{c}\mathrm{D} \\
\text { (No.) }\end{array}$ \\
\hline Coryphaenoides rupestris & 340.6 & 409.5 & 103.5 & 255.8 & Bathygadus melanobranchus & & & * & 0.02 \\
\hline Aphanopus carbo & 123.7 & 133.7 & * & 0.2 & Coryphaenoides guentheri & & & * & 0.04 \\
\hline Siki & 115.5 & 20.8 & & & Nesiarchus nasutus & & & * & 0.02 \\
\hline Hoplostethus atlanticus & 68.8 & 27.5 & & & Molva molva & & & * & 0.07 \\
\hline Molva dypterygia & 55.6 & 12.3 & * & 0.1 & Rouleina sp. & & & * & 0.3 \\
\hline Mora moro & 13.9 & 13.1 & * & 0.6 & Lycodes sp. & & & * & 0.02 \\
\hline Lophius piscatorius & 1.8 & 0.4 & & & Bathypterois dubius & & & * & 0.1 \\
\hline Trachyscorpia crist. echinata & 0.2 & 0.1 & & & Borostomias sp. & & & * & 0.02 \\
\hline Raja batis & * & 0.02 & & & Xenodermichthys copei & & & * & 0.04 \\
\hline Alepocephalus bairdii & & & 480.7 & 150.9 & Phycis blennoides & & & * & 0.2 \\
\hline Deania calcea & & & 101.8 & 31.7 & Synaphobranchus kaupi & & & * & 0.04 \\
\hline Lepidion eques & & & 31.9 & 88.0 & Helicolenus dactylopterus & & & * & 0.6 \\
\hline Trachyrincus murrayi & & & 29.0 & 117.5 & Gaidropsarus vulgaris & & & * & 0.3 \\
\hline Dalatiidae & & & 17.4 & 19.0 & Epigonus telescopus & & & * & 0.2 \\
\hline Hydrolagus mirabilis & & & 8.3 & 3.5 & Argentina silus & & & * & 0.04 \\
\hline Hydrolagus affinis & & & 6.3 & 14.5 & Antimora rostrata & & & * & 0.02 \\
\hline Caelorinchus labiatus & & & 4.9 & 19.8 & Glyptocephalus cynoglossus & & & * & 1.7 \\
\hline Alepocephalus rostratus & & & 4.7 & 5.4 & Argyropelecus sp. & & & * & 0.04 \\
\hline Rhinochimaera atlantica & & & 2.6 & 0.4 & Spectrunculus grandis & & & * & 0.02 \\
\hline Halargyreus johnsonii & & & 1.2 & 5.8 & Oxynotus paradoxus & & & * & 0.1 \\
\hline Harriotta raleighana & & & 0.5 & 0.2 & Pseudotriakis microdon & & & * & 0.02 \\
\hline Cottunculus thomsonii & & & * & 1.5 & Apristurus sp. & & & * & 3.5 \\
\hline Neocyttus helgae & & & * & 0.6 & Rajidae & & & * & 2.2 \\
\hline Notacanthus chemnitzii & & & * & 0.3 & Hexanchus griseus & & & * & 0.02 \\
\hline Notacanthus bonapartei & & & * & 0.2 & Dalatias licha & & & * & 0.1 \\
\hline Nezumia aequalis & & & * & 2.6 & & & & & \\
\hline
\end{tabular}

* Fish quantity too low to be weighed on-board.

\section{Results}

From the 55 hauls sampled, eight species or groups of species were identified as totally landed (Table 3 ). The most abundant were the black scabbard fish $A$. carbo, the 'siki' sharks and the orange roughy $H$. atlanticus. Forty-three species were totally discarded, of which $A$. bairdii was the most abundant. Only the roundnose grenadier C. rupestris, was both landed and discarded. Grenadier discards consisted of the smallest individuals and the discarding rate for this species was $23 \%$ by weight for pooled data, and $21.2 \% \pm 3.1$ ( $\pm 95 \%$-confidence interval) for mean by haul.

The total discarding rate, by weight, for pooled data was $52.4 \%$; an average four-hour haul contained $720 \mathrm{~kg}$ of landed species and $793 \mathrm{~kg}$ of discarded species. The mean total discarding rate by haul was $48.5 \% \pm 21.1$ (range: $2.4 \%-82.4 \%$ ).

Both the mean and pooled total and grenadier discarding rates increased with depth (Table 4). The mean total discarding rate rose significantly from $25.1 \%$ in the $800 \mathrm{~m}$ depth stratum to $55.4 \%$ in the $1000 \mathrm{~m}$ stratum and non-significantly to $60.9 \%$ in the $1200 \mathrm{~m}$ stratum. The mean grenadier discarding rate increased from $17.4 \%$ at $800 \mathrm{~m}$ to $19.9 \%$ and $28.2 \%$ at 1000 and $1200 \mathrm{~m}$, respectively, however, it is not statistically significant. The mean landings of commercial species concomitantly decreased non significantly from 871 to 679 and $626 \mathrm{~kg}^{4} \mathrm{~h} \mathrm{~h}^{-1}$ while the total discards increased significantly from 346 to $874 \mathrm{~kg} .4 \mathrm{~h}^{-1}$ and non-significantly to $1393 \mathrm{~kg} .4 \mathrm{~h}^{-1}$, at the 800,1000 and $1200 \mathrm{~m}$ depth strata respectively. 
Table 4.

Mean and pooled discarding rates in weight (\%) and mean quantities of discards and landings (kg.4 $\left.\mathrm{h}^{-1}\right)$ by four-hour haul and by depth zone, \pm confidence interval $(p=0.05)$.

\begin{tabular}{|c|c|c|c|c|c|c|c|}
\hline \multirow[t]{2}{*}{ Depth zone } & \multirow{2}{*}{$\begin{array}{l}\text { Number of } \\
\text { hauls } \\
\text { sampled }\end{array}$} & \multicolumn{2}{|c|}{$\begin{array}{c}\text { Total } \\
\text { discarding rate (\%) }\end{array}$} & \multicolumn{2}{|c|}{$\begin{array}{c}\text { Grenadier } \\
\text { discarding rate (\%) }\end{array}$} & \multirow{2}{*}{$\begin{array}{c}\text { Quantity of total } \\
\text { landings } \\
\left(\mathrm{kg} .4 \mathrm{~h}^{-1}\right) \\
\end{array}$} & \multirow{2}{*}{ 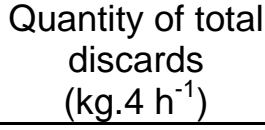 } \\
\hline & & mean & pooled & mean & pooled & & \\
\hline 800-999 & 15 & $25.1 \pm 6.0 *$ & 28.5 & $17.4 \pm 5.4^{\circ}$ & 21.9 & $871 \pm 309^{\circ}$ & $346 \pm 171^{*}$ \\
\hline $1000-11$ & 27 & $55.4 \pm 5.6^{\circ}$ & 56.1 & $19.9 \pm 4.0^{\circ}$ & 21.3 & $679 \pm 161^{\circ}$ & $874 \pm 199^{\circ}$ \\
\hline $1200-1399 \mathrm{~m}$ & 13 & $61.0 \pm 11.0$ & 66.5 & $28.2 \pm 6.5$ & 30.9 & $626 \pm 226$ & $1393 \pm 709$ \\
\hline
\end{tabular}

* Value statistically different from the following value, Mann \& Whitney $p<0.05$

- Value non-statistically different from the following value, Mann \& Whitney $p>0.05$

Catch composition also varied with respect to depth (Table 5). The grenadier $C$. rupestris was the most abundant species caught in the $800 \mathrm{~m}$ depth stratum with $38.4 \%$, whereas $A$. bairdii became preponderant in the 1000 and $1200 \mathrm{~m}$ depth strata with $35.1 \%$ and $50.9 \%$, respectively, against $28.7 \%$ and $22.3 \%$ for $C$. rupestris. The grenadier, however, was the most abundant species landed, whatever the depth. The percentage of the second species landed at $800 \mathrm{~m}$, the black scabbard fish $A$. carbo decreased when fishing deeper whereas siki and orange roughy $H$. atlanticus percentages rose. Moving from $800 \mathrm{~m}$ to $1000 \mathrm{~m}$, and $1200 \mathrm{~m}$ showed a substantial increase of $A$. bairdii in the discards whereas there were less Deania calcea and Lepidion eques. The grenadier discards remained at the same level and the other discarded species generally represented less than $1 \%$ of the total catch by weight.

Table 5.

Percentage of landed (L) and discarded (D) species that represent more than $0.1 \%$ of the weight of the catch by depth range $(\mathrm{m})$.

\begin{tabular}{|c|c|c|c|c|c|c|}
\hline & \multicolumn{2}{|c|}{$800-999 \mathrm{~m}$} & \multicolumn{2}{|c|}{$1000-1199 \mathrm{~m}$} & \multicolumn{2}{|c|}{$1200-1399 \mathrm{~m}$} \\
\hline & $\mathrm{L}$ & D & $\mathrm{L}$ & D & $\mathrm{L}$ & $\mathrm{D}$ \\
\hline Coryphaenoides rupestris & 30 & 8.4 & 22.6 & 6.1 & 15.4 & 6.9 \\
\hline Aphanopus carbo & 19.8 & & 6.2 & & 1.7 & \\
\hline Siki & 7 & & 6.8 & & 9.9 & \\
\hline Hoplostethus atlanticus & 0.2 & & 5.5 & & 6.5 & \\
\hline Molva dypterygia & 11 & & 2.2 & & & \\
\hline Mora moro & 2.9 & & 0.5 & & & \\
\hline Lophius piscatorius & 0.5 & & & & & \\
\hline Alepocephalus bairdii & & 3.1 & & 35.1 & & 50.9 \\
\hline Deania calcea & & 11.9 & & 7.4 & & 0.7 \\
\hline Lepidion eques & & 3.9 & & 2.2 & & 0.3 \\
\hline Trachyrincus murrayi & & & & 2.3 & & 2.8 \\
\hline Dalatiidae & & 0.1 & & 1 & & 3 \\
\hline Hydrolagus mirabilis & & 0.4 & & 0.7 & & 0.4 \\
\hline Hydrolagus affinis & & 0.6 & & 0.4 & & 0.2 \\
\hline Caelorinchus labiatus & & & & 0.3 & & 0.7 \\
\hline Alepocephalus rostratus & & & & 0.3 & & 0.6 \\
\hline Rhinochimaera atlantica & & & & 0.2 & & 0.4 \\
\hline Halargyreus johnsonii & & & & 0.1 & & 0.1 \\
\hline
\end{tabular}

The total discards of the deepwater fishery were estimated to be approximately $26050 \pm 12500 \mathrm{t}$ and $18500 \pm 5600 \mathrm{t}$ in 1996 and 1997, respectively, based on the mean ratio, and 17528 and $17423 \mathrm{t}$, respectively, based on the pooled ratio (Table 6). The high value observed in 1996 when calculated with the mean ratio is an anomaly induced by the large amount of $A$. bairdii caught in one haul. By removing this data, total discard estimates were $20681 \pm 8077 \mathrm{t}$ in 1996, probably a more realistic value, closer to the one obtained by calculating with the pooled ratio. These quantities of discards 
were in the same range as the total landings of all the deepwater fish, 19650 and $19100 \mathrm{t}$ in 1996 and 1997, respectively. More grenadiers were discarded in 1996 than in 1997, although landings were similar (ca. 7300 t).

Table 6.

Annual weights of discarded species estimated from the mean and pooled discarded-to-landed ratios (Table 2) and the annual landings of grenadiers in 1996 and 1997, \pm confidence interval $(p=0.05)$.

\begin{tabular}{llcccc}
\hline & & \multicolumn{2}{c}{$1996(\mathrm{t})$} & \multicolumn{2}{c}{$1997(\mathrm{t})$} \\
& & mean & pooled & mean & pooled \\
\hline Annual landings & Landed grenadier & 7277 & \multicolumn{2}{c}{7287} \\
& All deep-sea fish & 19652 & \multicolumn{1}{c}{19103} \\
\hline Annual estimations & Discarded grenadier & $2329 \pm 509$ & 2278 & $1530 \pm 510$ & 1564 \\
& Caught grenadier & $9606 \pm 509$ & 9555 & $8817 \pm 510$ & 8851 \\
& Discarded $A$. bairdii & $18702 \pm 11934$ & 11216 & $13626 \pm 5100$ & 12859 \\
& Discarded other species & $5021 \pm 1327$ & 4034 & $3352 \pm 1166$ & 3000 \\
& All discarded deep-sea fish & $26052 \pm 12515$ & 17528 & $18509 \pm 5611$ & 17423 \\
\hline
\end{tabular}

* The main eight species in Table 3.

The pre-anal lengths of discarded grenadiers C. rupestris ranged from 4 to $19 \mathrm{~cm}$ (mean: $12.8 \mathrm{~cm}$ ), whereas the landed grenadiers measured from 10.5 to $27 \mathrm{~cm}$ with a mean length of $17.9 \mathrm{~cm}$ (Fig. 1). The discards mainly consisted of males because they were smaller (mean length: $14.3 \mathrm{~cm}$ ) than females (mean length: $18.1 \mathrm{~cm}$ ) (Allain and Kergoat, 1997). The modes of the grenadier lengthfrequency distribution were difficult to distinguish, whatever the depth. The smallest fish were observed in the $800 \mathrm{~m}$ and $1000 \mathrm{~m}$ depth zones, but the proportion of juvenile fish increased with depth. Juveniles corresponded to individuals below $11.5 \mathrm{~cm}$, the size at first female maturity according to Allain (2001) (male maturity was more difficult to establish with accuracy). These juveniles accounted for $9.6 \%, 11.1 \%$ and $17.1 \%$ of the fish in the $800 \mathrm{~m}, 1000 \mathrm{~m}$ and $1200 \mathrm{~m}$ depth zones, respectively. The mean length of the total catch correspondingly decreased from $15.6 \mathrm{~cm}$ at $800 \mathrm{~m}$ to $14.6 \mathrm{~cm}$ at $1200 \mathrm{~m}$. Thus, if we consider a constant catchability of grenadiers of different development stages with depth, most grenadier juveniles live in the 1200-1400 m bathymetric zone, the maximum depth investigated in this study, whereas adults are more widely distributed. These results are consistent with the hypothesis of a bathymetric ontogenic migration undertaken by $C$. rupestris.

Standard lengths of $A$. bairdii ranged between $6 \mathrm{~cm}$ and $88 \mathrm{~cm}$ (Fig. 1). The biggest fish (mean length: $59.1 \mathrm{~cm}$ ) were found in the 1000-m-bathymetric zone, the smallest (mean length: $48.6 \mathrm{~cm}$ ) in the 800$\mathrm{m}$ zone, and the intermediate (mean length: $54.0 \mathrm{~cm}$ ) in the $1200-\mathrm{m}$ zone. The length-frequency distributions in the different bathymetric zones were bimodal. Whereas the upper mode was similar in the three zones (ca. $66 \mathrm{~cm}$ ), the position of the lower mode varied with depth and increased from 23$24 \mathrm{~cm}$ at $800 \mathrm{~m}$, to $30 \mathrm{~cm}$ at $1000 \mathrm{~m}$ and $45 \mathrm{~cm}$ at $1200 \mathrm{~m}$. The proportions of fish in the two modal groups also varied with depth. When going deeper into the three bathymetric zones, the smaller fish represented $34.4 \%, 9.3 \%$ and $59.8 \%$ of the population, respectively. So, the small fish live mainly in the 800-m-depth zone. While still growing, they swim across the $1000-\mathrm{m}$-bathymetric zone to finally settle in the $1200-\mathrm{m}$ zone, where they become sexually mature at $55 \mathrm{~cm}$ for females and $58 \mathrm{~cm}$ for males (Allain, 1999b). Once mature, adults are found at all depths, but concentrate in the 1000-m zone. Thus, A. bairdii also seems to undertake a bathymetric ontogenic migration. 
Fig.1. Length-frequency distributions of Coryphaenoides rupestris and Alepocephalus bairdii by depth: 800999 m (A), 1000-1199 m (B), 1200-1399 m (C).
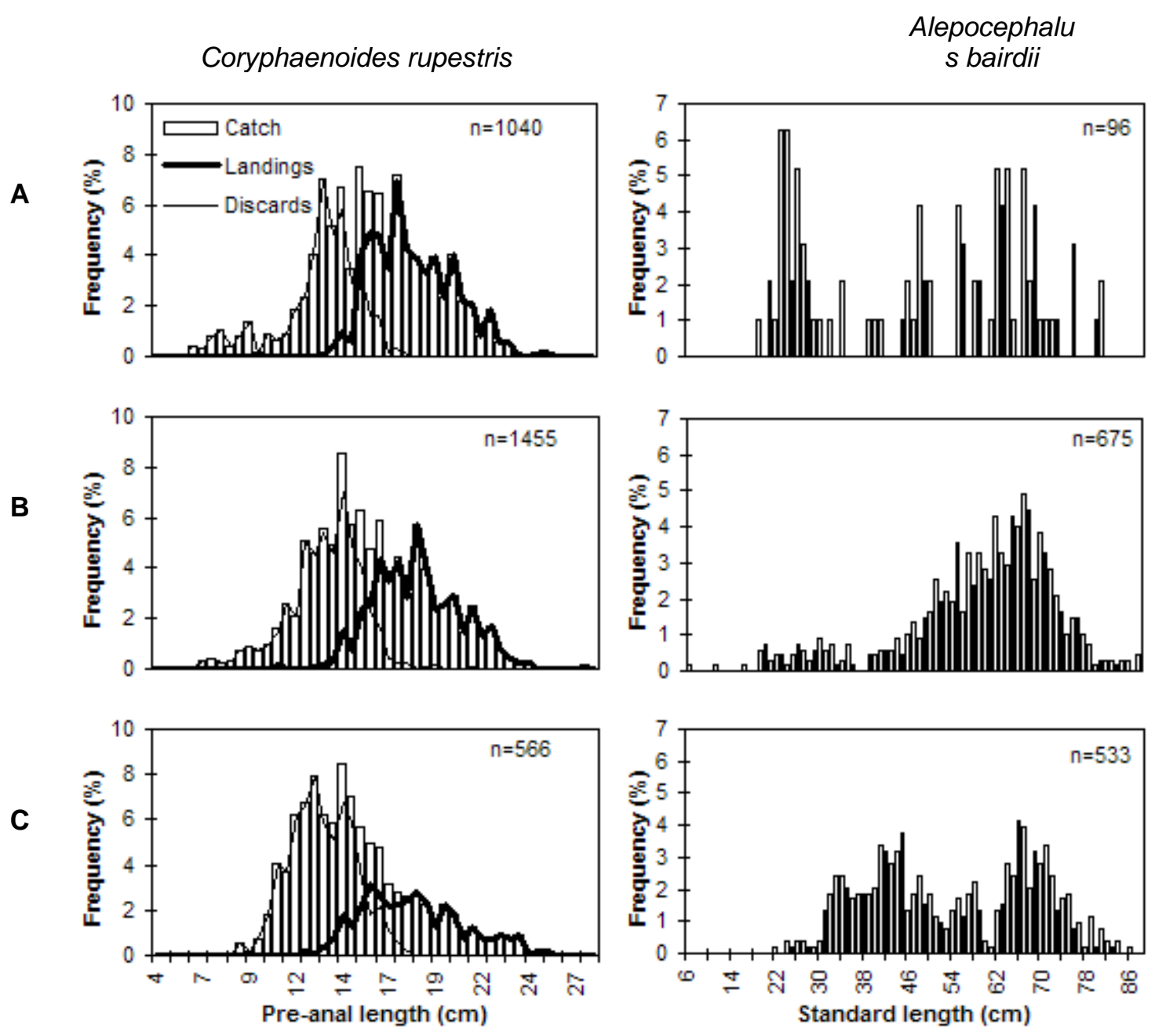

\section{Discussion}

The estimates of discarding rates and of the annual discarded quantities presented here should be regarded as preliminary. Comparing these preliminary results with those obtained by Connolly and Kelly (1996) in the same geographical area and depth-range on an Irish demersal trawler in November-December 1995, some differences appear. Indeed, in their study, sharks were the most abundant discards, followed by grenadiers, and the weights of $A$. bairdii were extremely low. The discard rates, as defined in the present study and calculated from Connolly and Kelly data, accounting to $31.5 \%$ for total discards and $12.4 \%$ for grenadier discards, were below ours, 48.5 and $21 \%$, respectively. Connolly and Kelly estimated the total discards of deepwater fish in ICES area VI in 1995 to be $7520 \mathrm{t}$. The relatively small quantities of $A$. bairdii in their samples can explain the difference with our results (ca. 17500 for pooled ratio). Another study conducted in September 1996 on commercial trawlers in the same area (Kelly et al., 1997) provided a total discards estimate of $16783 \mathrm{t}$, which was closer to our results.

Still keeping in mind the preliminary nature of the results, the French deep-sea trawling fishery, with a mean total discarded-to-landed ratio by weight of $1.396 \pm 0.369$ (pooled ratio is 1.101), should rank below the top 20 fisheries with the highest ratios (14.71 - 2.01; the 10 lowest ratios are from 0.118 to 0.011) (Alverson et al., 1994). The fishery under study is in the lowest part of the range of highest ratios for non-pelagic fish trawl (5.28 - 2.01). 
Using the mean and the pooled ratios gave different results in the estimation of the discards. As observed by Hay et al. (1999), estimates based on the mean of individual tows appear to overestimate discards. These authors conclude that estimates based on the pooled ratio are more reliable. Because the distributions of the discarded-to-landed ratios are not normal, the mean is not a good representative of the data set, the pooled ratios are better representations of the diversity of the data. In this study, however, only 55 hauls were sampled over a two-year period, representing a coverage rate of $0.13 \%$. The sampling took place on two sister-ships from the same fleet. This sampling is then poorly representative of the normal haul-to-haul variability in quantity and composition of the catch, and both mean and pooled data are subject to great uncertainty. The haul-to-haul variability can be explained by several factors. First it appears that some species such as $A$. bairdii or $H$. atlanticus are caught in large aggregations, which implies a non-regular or non-random spatial distribution of the fish. Second, variations in densities are highly probable according to the area and depth, bottom type and other abiotic and biotic factors. And third, variations in the composition of the species assemblage are also observed. The low representative sampling, when considering the haul-to-haul variability, explains the great uncertainty of the results.

To improve the accuracy of the discard estimates it is necessary to increase the coverage rate and to stratify the sampling strategy. Simulations conducted by Vølstad et al. (1997) indicated that with random selection of observed trawlers, estimates with acceptable error bounds can be made for frequently occurring species by sampling $30 \%$ of the vessels. For less frequently occurring species, a much larger proportion of the fleet would need to be sampled. Hence the need to increase the coverage rate is considerable and a stratification by fleet seems essential. This stratification was used by Blasdale and Newton (1998) (large and small high sea trawlers) in the same area, and according to the analyses of Lorance and Dupouy (2001), three French fleets showing different fishing powers should be sampled: two fleets of large offshore trawlers (49-55 m long) and one fleet of smaller highseas trawlers (30-38 $\mathrm{m}$ long). Another factor that should be taken into account for the stratification of the sampling is the depth. Actually, as underlined in this study and by Lorance (1998), depth is a major factor in the determination of species composition and discard rates. As also highlighted by Blasdale and Newton (1998), the depth-related variations of discarding rates and quantities are linked to differences in species composition of the fish communities and in the length-frequency distribution of some species. Species replace each other according to their bathymetric and geographical preferences. Thus, A. bairdii is particularly abundant between 1000 and $1250 \mathrm{~m}$, which explains the increase of both discarding rate and fish biomass in the $1000 \mathrm{~m}$ bathymetric zone in the Northeast Atlantic Ocean (Gordon, 1986). The increase with depth in the discarding rate for C. rupestris, although not statistically significant, is due to the fact that individuals too small for marketing were mainly observed in the deepest area exploited as shown in this study. The calculation of a discardedto-landed ratio by depth range should improve the accuracy of estimates, but it also implies depthstratified fishery statistical data, which are not available at the present time.

In the deepwater fishery, most species are totally discarded, including some large-bodied species such as $A$. bairdii. An increase in mesh size would therefore not lower the discarding rate in the deepwater fishery. Furthermore, many deepwater fish have fragile skin that is quickly damaged by friction with other fish or with trawl meshes, which is likely to compromise the survival of fish escaping from the trawl (Connolly and Kelly, 1996; Kelly et al., 1998). Discarding could be reduced by developing a commercial market for the discarded species as has been done in Iceland in collaboration with professionals (Thorsteinsson and Valdimarsson, 1995). However, attempts in France to market A. bairdii, which can account for up to $70 \%$ of the discards by weight, were unsuccessful.

\section{Acknowledgement}

This research was funded by the Brittany region and European Commission FAIR Project 95/0655, "Developing deep-water fisheries: data for their assessment and for understanding their interaction with and impact on a fragile environment". The authors would like to thank the crews of "Croix-Morand" and "Lioran" from Dhellemmes, L. Quiniou, H. Dupouy, P. Williams, T. Lawson and K. Des Rochers.

\section{References}

Allain, V. 2001. Reproductive strategies of three deep-water benthopelagic fishes from the northeast Atlantic Ocean. Fish. Res. 51, 165-176. 
Allain, V., 1999a. Ecologie, biologie et exploitation des populations de poissons profonds de I'Atlantique du nord-est. Ph-D Thesis. Université de Bretagne Occidentale, Brest.

Allain, V., 1999b. Fecundity of the deep-sea fish in the north-east Atlantic Alepocephalus bairdii (Pisces: Alepocephalidae). J. Mar. Biol. Ass. UK. 79, 765-767.

Allain, V., Kergoat, B., 1997. Biodiversité et stratégies démographiques des populations de poissons profonds de l'Atlantic Nord-Est soumises à la pression de la pêche. Vie Milieu. 47, 285-294.

Alverson, D.L., Freeberg, M.H., Murawski, S.A., Pope, J.G., 1994. A global assessment of fisheries bycatch and discards. FAO Fish. Tech. Pap. 339, 233p.

Blasdale, T., Newton, A.W., 1998. Estimates of discards from two deepwater fleets in the Rockall trough. ICES CM 1998/. O:11, 18p.

Charuau, A., Dupouy, H., Lorance, P., 1995. French exploitation of the deep-water fisheries of the North Atlantic. In: Hopper, A.G. (Ed.), Deep-water fisheries of the North Atlantic oceanic slope. Kluwer Academic Publishers, The Netherlands, 337-356.

Connolly, P.L., Kelly, C.J., 1996. Catch and discards from experimental trawl and longline fishing in the deep water of the Rockall Trough. J. Fish Biol. 49, supplement A, 132-144.

Gordon, J.D.M., 1986. The fish populations of the Rockall Trough. Proc. Roy. Soc. Edinburgh. 88B, 191-204.

Hay, D.E., Hardo, R., Boutillier, J., Wylie, E., Convey, L., McCarter, P.B., 1999. Assessment of bycatch in the 1997 and 1998 shrimp trawl fisheries in British Columbia, with emphasis on eulachons. Canadian Stock Assessment Secretariat Res. Doc. 99/179, 44p. Fisheries and Oceans Canada. Nanaimo, British Columbia.

Kelly, C.J., Clarke, M., Connolly, P.L., 1997. Catch and discards from a deep-water trawl survey in 1996. Fish. Leaf. 175, 1-16. Marine Institute. Dublin.

Kelly, C.J., Connolly, P.L., Clarke, M.W., 1998. The deep water fisheries of the Rockall trough; some insights gleaned from Irish survey data. ICES CM 1998/. O:40, 22p.

Lorance, P., 1998. Structure du peuplement ichtyologique du talus continental a l'ouest des îles Britanniques et impact de la pêche. Cyb. 22, 309-331.

Lorance, P., Dupouy, H., 2001. C.P.U.E. abundance indices of the main target species of the French deep-water fishery in ICES sub-areas V-VII. Fisheries Research. 51, 137-149.

Saila, S.B., 1983. Importance and assessment of discards in commercial fisheries. FAO Fish. Cir. 765, 1-62.

Thorsteinsson, H.P., Valdimarsson, G., 1995. Experimental utilisation and marketing of by-catches and deep water species in Iceland. In: Hopper, A.G. (Ed.), Deep-water fisheries of the North Atlantic oceanic slope. Kluwer Academic Publishers, Netherlands, 377-384.

Vølstad, J.H., Richkus, W., Gaurin, S., Easton, R., 1997. Analytical and statistical review of procedures for collection and analysis of commercial fishery data used for management and assessment of grounfish stocks in the U.S. exclusive economic zone of Alaska. Versar, Inc. NMFS Alaska Fisheries Science Center. Seattle, Washington.

Whitehead, P.J.P., Bauchot, M.L., Hureau, J.-C., Nielsen, J., Tortonese, E., Eds. 1984. Fish of the north-eastern Atlantic and Mediterranean. vol. 3. UNESCO, Paris. 